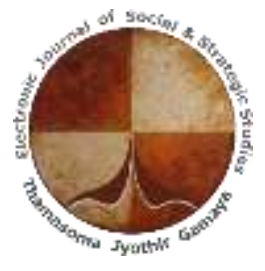

\author{
Electronic Journal of Social and Strategic Studies (EJSSS) \\ Special Issue: Citizenship and Globalization
}

Preface to the Special Issue \& Editor's Note

Citizenship was conceived as a consortium of duties and rights within which members of societies (nations) tended to be viewed. This conventional understanding underwent a major change with the advent of UDHR, resulting in an International Human Rights Regime that composes of international, multilateral, regional and national instruments with as many monitoring and implementation mechanisms. Even as the norms of behavior by states and sovereigns came to be viewed through the lens of these instruments, the process of globalization introduced as many opportunities and challenges to expound the meaning and content of citizenship. With NonResident contributions to national economies, the distinctive impact of these forms of citizenship also tended to extend their influence into the arena of political decision making.

Global migration prompted by poverty, mis-governance, organized crime, inter and intra state armed violence are also prompting governments to re-visit citizenship laws and adopt measures to purportedly defend their national interests. Impacts of these occurrences in contemporary times lends a necessity to revisit the concept of citizenship in its multifarious dimensions and impacts.

\title{
About the Special Issue
}

Keeping the above mentioned briefly stated contexts in mind, the Special Issue aims to collate scholarly discourses, empirical as well as case studies, in order to expand our understanding of the concept of citizenship in the era of globalization. In doing so, EJSSS aims to facilitate learned debates and lessons for addressing geopolitical and geo-economic scenarios that have an umbilical connection to the concept of citizenship in our world.

\section{About EJSSS}

Electronic Journal of Social and Strategic Studies is an Open Access, refereed (blind review) research journal. We are a member journal of Crossref and papers published carry doi. Our case for ISSN is in process. Our Editorial and Review Boards consist of eminent professors, scholars and practioners from academia and strategic domains. We publish at www.ejsss.net.in

We have no Article Submission Charges. We also have no Article Processing Charges for now, in order to encourage emerging scholars in social sciences and strategic studies.

We believe knowledge shared is knowledge multiplied. 


\section{CONTENTS}

\section{Articles}

1. The Concept of Citizenship and the Democratic State

Dr Sureyya Yigit

https://doi.org/10.47362/EJSSS.2021.2301

2. Citizenship and Discontents: A Socio-Legal Analysis

Dr. Bhupinder Singh and Dr. Vidyottma Jha

https://doi.org/10.47362/EJSSS.2021.2302

3. Statelessness and forced displacement in the era of post-globalization:

A Case Study on Rohingya Crisis

Athulya

https://doi.org/10.47362/EJSSS.2021.2303

4. Inter-relationship between Citizenship and Globalization:

An India Specific Analysis

Cmde SL Deshmukh, NM (Retd)

https://doi.org/10.47362/EJSSS.2021.2304

5. Political Citizenship: Exploring the Precept of Acceptance of State Legitimacy through Indian Independence Movement

Dr R Srinivasan

https://doi.org/10.47362/EJSSS.2021.2305 


\section{Author Short Bio}

Dr Sureyya Yigit is Professor of Politics and International Relations, School of Politics and Diplomacy, New Vision University, Bokhua Street No:9, 0159, Tbilisi, Georgia.

Dr. Bhupinder Singh is Associate Professor, School of Law, CHRIST (Deemed to be University) Delhi- NCR, India and Dr. Vidyottma Jha is an Advocate, Supreme Court of India, New Delhi, India.

Dr Athulya is an Assistant Professor- Political Science, Reva University, Yelhankha, Bengaluru64, India.

Commodore SL Deshmukh, NM (Retd) served the Indian Navy for over three decades as a specialist in maintenance of fighter aircraft and ASW helicopters. He is currently the Senior Vice President of Sun Group's Aerospace \& Defence vertical.

Dr R Srinivasan is a Ph.D. in Political Sociology and an independent researcher, based at Coimbatore, Tamil Nadu, India.

\section{Editor's Note}

Electronic Journal of Social and Strategic Studies (EJSSS) encourages young and emerging scholars across the world to publish their works. We accept research papers, case studies, book reviews, synopsis of thesis approved for publication. Scholars and researchers interested in contributing to the journal are welcome to mail the Managing Editor at submission.ejss@gmail.com with their abstracts.

Regular Issues of the journal are published three times a year in April-May, August-September and December January.

Special Issues on topics of contemporary or topical relevance in the subject areas of interest to the journal are published at various intervals.

EJSSS also holds webinars and conferences on topics of contemporary importance. We have held six such webinars jointly with renowned universities/organizations in 2020-21 till now. Proposals from Research Institutions, university departments and Think Tanks in areas of mutual interest 
may be mailed to submission.ejss @ gmail.com. Papers presented in such events are also published as Special Issues.

\section{Open Access to Contents}

EJSSS believes in and practices Open Access policy. Papers published by the journal are available online without any restrictions on accessing the full content.

\section{Copyrights and Plagiarism Policy}

The copyright of the works published in our journal belongs to the contributing authors. They are welcome to use, reuse, distribute, modify or update their content published in this journal in any platform in any manner deemed appropriate towards further research. We only request that appropriate first publication credit to be given to EJSSS. Since all publications in our journal carry doi, giving such credit to us would be in keeping with our own policy on the subject.

We are a not-for-profit journal and take reasonable efforts to have the works published by us checked for plagiarism. The responsibility and ownership of the content therefore rests with the authors. As publishers, we accept no liability for copyright related issues. We emphasize upon the authors to make every endeavor to provide original content, unpublished earlier, giving appropriate citations for resources consulted in producing their work.

Coimbatore, India

31 May 2021
Dr R Srinivasan

Editor-in-Chief \& Managing Editor 